\title{
Rola dzieci i młodzieży w procesach partycypacji społecznej
}

\author{
Natalia Przesmycka \\ Katedra Architektury, Urbanistyki i Planowania Przestrzennego. \\ Wydziat Budownictwa i Architektury Politechniki Lubelskiej
}

\begin{abstract}
Streszczenie: Partycypacja społeczna jest obecnie nieodłącznym elementem procesów rewitalizacji, a te z kolei stanowią jeden z nurtów projektowania urbanistycznego. W kształtowaniu współczesnych przestrzeni publicznych i półpublicznych, nie tylko w środowiskach zabudowy mieszkaniowej, ważną rolę pełnią szeroko rozumiane place zabaw i przestrzenie rekreacyjne. Powoduje to, że dzieci i młodzież stają się coraz częściej równouprawnionymi uczestnikami procesu zarządzania i planowania miastem, jako współuczestniczący w planowaniu, projektowaniu, a czasem nawet budowaniu dedykowanych im przestrzeni.
\end{abstract}

Słowa kluczowe: przestrzeń publiczna, place zabaw, partycypacja społeczna, dzieci w przestrzeni publicznej, partycypacja dzieci i młodzieży

\section{Dzieci i młodzież jako docelowe grupy partycypacji społecznej w procesie zarządzania miastem}

Dzieci w przestrzeni publicznej miast funkcjonowały od zawsze, jednak dopiero od niedawna zaczęto postrzegać je jako równoprawnych użytkowników. Tradycyjnie miejscem zabaw dziecięcych były przestrzenie towarzyszące miejscom zamieszkania, przyległe ulice i podwórka. Dopiero od końca XIX wieku zaczęto projektować przestrzenie do zabaw i spędzania wolnego czasu w publicznych parkach, a w XX wieku pojawiły się w krajobrazie miejskim place zabaw powiązane najczęściej ze strefami zabudowy mieszkaniowej.

Projektowanie urbanistyczne stało się obecnie procesem, w którym oprócz wizji projektantów i zarządzających terenem, ważne jest silne zaangażowanie odbiorców docelowych, którymi są różne grupy społeczne. Dzieci i młodzież powinny być traktowane podmiotowo, jako docelowi odbiorcy i uczestnicy działań opartych na partycypacji społecznej, nieodłącznie związanej z ustrojem demokratycznym. Podstawę dla takiego postrzegania dzieci dała przyjęta przez Zgromadzenie Ogólne ONZ dnia 20 listopada 1989 roku Konwencja o Prawach Dziecka. Konwencja uznaje prawa dziecka do nieskrępowanego uczestnictwa w życiu kulturalnym i artystycznym, gwarantuje dzieciom prawo do zabawy, wypoczynku i czasu wolnego oraz uczestniczenia w zabawach i zajęciach rekreacyjnych. Artykuł 12 sankcjonuje prawo dzieci do swobodnego wyrażania własnych poglądów w sprawach ich dotyczących oraz przyjmowania tych poglądów z należytą powagą stosownie do zdolności dziecka. Konwencja podkreśla, że zabawa jest jednym z integralnych elementów dzieciństwa. Z kolei obowiązkiem każdego, kto umożliwia zabawę, jest zapewnienie ochrony zdrowia i życia. Zadaniem rodziców i opiekunów jest pomoc w jej trakcie oraz nieograniczenie prawa dziecka do ekspresji. ${ }^{1}$

Obecnie w procesie zarządzania miastem, partycypacja społeczna stała się nieodzownym elementem między innymi procesów rewitalizacji urbanistycznej i odnowy miejskiej, zaś rewitalizacja urbanistyczna jednym z głównych nurtów współczesnej urbanistyki. Projektowanie urbanistyczne jest obecnie procesem silnego zaangażowania odbiorców docelowych - różnych grup społecznych, zaś sama partycypacja oprócz zapewnienia większej celowości działań projektantów, wzmacnia społeczny rozwój społeczny. 
Od lat 90-tych XX wieku rolę dzieci i młodzieży w procesach partycypacyjnych dostrzegli badacze, najpierw w kontekście socjologicznym. Roger Hart (1992) wskazuje cechy, jakie powinny charakteryzować partycypację społeczną z udziałem dzieci. Są to: zrozumienie przez dzieci intencji projektu, warunek dobrowolności ich udziału lub podjęcie własnej inicjatywy przez dzieci, rozumienie zasad własnego uczestnictwa, jego wagi i mocy wpływu na decyzje dorosłych, rzeczywistym reprezentowaniu rówieśników, oraz zapewnienie dzieciom swobody formy wypowiedzi [Hart 1992]. Wskazuje on również na zagrożenia występujące podczas procesu partycypacji, takie jak: możliwość manipulowania dziećmi, pozorne zaangażowanie dzieci w procesie decyzyjnym „dekorowanie się dziećmi”, wiążące się ze zjawiskiem „tokenizmu”, czyli pozornego udzielania głosu.

U progu XXI wieku tematyka ta staje się przedmiotem zainteresowania również urbanistów i architektów. E. Jarosz podkreśla, że partycypacja młodych ludzi w rozwoju obywatelskich społeczności lokalnych i zaangażowania obywatelskiego ma duże znaczenie zarówno na poziomie lokalnym, jak i państwowym. Współcześnie rozumiana partycypacja nie ogranicza się jedynie do współdecydowania w kwestiach dotyczących bezpośrednio dzieci i młodzieży [Jarosz 2016]. Socjologiczne oraz interdyscyplinarne badania podkreślają zmianę statusu dziecka w społeczeństwie. Dzieci nie są już pasywnymi „obiektami” opieki, starań i decyzji dorosłych, lecz częściej współdecydentami w kwestiach społecznych [Warming 2003, p. 815., Lansdowne 2010]. Jednak, jak zauważa Jarosz rola dzieci i młodzieży „w praktyce społecznej i politycznej jest poważnie wypaczana i realizowana jedynie powierzchownie".

M. Lozanowska i L. Xu wyróżniają cztery modele partycypacji społecznej z udziałem dzieci: "głos dzieci" w procesie projektowym, „projektowanie przez dzieci”, model socjologiczny, „projektowanie z dziećmi”, oraz wprowadzają własny model określony jako "model pedagogiczny” [Lozanowska, Xu, 2013]. ${ }^{2}$ W większości przypadków partycypacja odnosi się do projektowania przestrzeni i budynków, których głównymi użytkownikami są dzieci. Poszczególne modele mają swoje zalety i ograniczenia. W modelu "głos dzieci", formułowane przez grupę dzieci życzenia są wskazówką dla projektantów, a dzieci występują w roli doradców lub recenzentów. Głos doradczy grupy dzieci jest uśrednieniem ich opinii i potrzeb. Wadą tego modelu jest niemożliwość wysłuchania indywidualnych potrzeb tych dzieci, które mają problemy z ich artykulacją, lub są z jakiś względów marginalizowane. Problemem może być również konieczność „przełożenia” głosu dzieci na dojrzałe decyzje projektowe, co dodatkowo utrudnia fakt, że większość technik konsultacyjnych opracowana została jako skierowanych do dorosłych [Matthews 2001]. Model partycypacji polegający na projektowaniu przez dzieci najczęściej ogranicza się do placów zabaw. Bezpośrednio projektowanie a nawet budowanie przez dzieci placów zabaw pojawiało się sporadycznie i odnosiło się przede wszystkim do idei tzw. przygodowych placów zabaw. ${ }^{3} \mathrm{~W}$ rzeczywistości taki model partycypacji jest mocno ograniczony, ponieważ w swoim założeniu eliminuje wkład dorosłych w proces projektowania. Może prowadzić to do sytuacji, gdy do procesu włączone są jedynie najzdolniejsze dzieci [Newmana, Thomasa 2008] ${ }^{4}$. Najbardziej rozpowszechnionym modelem partycypacji z udziałem dzieci jest model wykorzystujący badania socjologiczne. Polega on na badaniu różnych aspektów funkcjonowania dziecka w środowisku zamieszkania i interpretowaniu wyników pod kątem poprawy jakości badanej przestrzeni. Jest to również model chętnie wykorzystywany przez badaczy przestrzeni miejskiej i architektury. ${ }^{5}$ Partycypacja społeczna może być również realizowana w modelu polegającym na "projektowaniu z udziałem dzieci”. Jest to najprawdopodobniej najbardziej zaawansowany model, ponieważ dzieci są nie tylko doradcą projektanta, lecz również włączone są aktywnie w proces projektowy poprzez współpracę z profesjonalistami [Bartlett 2002, Driskell 2002]. Partycypacja społeczna z udziałem dzieci jest potrzebna również na etapie zarządzania już istniejącymi przestrzeniami placów zabaw i terenów rekreacyjnych, tak by bieżące ich utrzymanie, czy też wprowadzane podczas eksploatacji zmiany, odpowiadały potrzebom użytkowników - dzieci [Jansson 2015].

2 Tłumaczenie własne, w org. "children's Voice model, "design by children" model, "social scientist for children', "design with children".

3 W 1931 roku C. Th. Sørensen, duński architekt krajobrazu, zauważył, że dzieci wolą się bawić wszędzie poza placami zabaw przez niego zaprojektowanymi. Takie idealne miejsca zabaw nazwał "śmieciowymi placami zabaw" (junk playground). Były to miejsca, w których , podobnie jak w miejscach zabaw dzieci na wsi, dziecko może samo kształtować i budować przestrzeń. jego idee rozpoczęły ruch zwany „przygodowymi placami zabaw adventure playground

4 Opisany przykład projektu wyposażenia szkoły, w której projektowanie zostało włączonych jedynie 15 spośród 1460 uczniów [Newman Thomas, 2008].

5 Lynch K. Growing up in cities: studies of the special environment of adolescence in Cracow, Melbourne, Mexico City, Salta, Toluca and Warsaw, Cambridge, MA; MIT Press, 1977, 177 pp. W czterech krajach przebadano po 20 nastolatków, co uznawane było za niewystarczające i zbyt mało reprezentatywne jako wyniki badań, Są to bardziej impresje niż fakty, jednak cenne jest samo zwrócenie uwagi na potrzeby młodych ludzi. 
Kolejnym pozytywnym aspektem aktywnego udziału dzieci i młodzieży w zarządzaniu miastem poprzez udział w życiu lokalnej społeczności, jest rozwijanie zaangażowania obywatelskiego i kształtowania tożsamości z „małą ojczyzną". W społecznościach, „które umożliwiają partycypację wszystkim mieszkańcom niezależnie od wieku, rośnie poziom społecznego zaangażowania i satysfakcji z udziału w życiu publicznym, umacnia się postawa współodpowiedzialności za podejmowane decyzje, wzrasta społeczna integracja i poziom społecznego zaufania oraz poparcia dla instytucji demokratycznych" [Brzozowska-Brywczyńska 2013].

Mówiąc o miejscu młodzieży w życiu społecznym miasta, częstym jest postrzeganie tej grupy społecznej jako problematycznej czy wręcz trudnej, a nawet stwarzającej zagrożenia. Jednak dostrzegając w młodzieży grupę potencjalnych współuczestników procesów przemian w miejscu zamieszkania, młodzież może być traktowana jako aktywny uczestnik i świadomy odbiorca, a nie jako zagrożenie i problem. Co gorsze wielu młodych ludzi, akceptuje wykreowany przez dorosłych wizerunek „problematycznej czy trudnej młodzieży”, co powoduje, że nie widzą siebie samych, jako pełnowartościowych uczestników życia społecznego.

Partycypacja społeczna młodzieży może być traktowana jako potencjał, a nie jako zagrożenie i problem. Młodzież chętnie włącza się w proces budowania, co pokazuje hiszpański przykład budowy sketeparku, opisany w dalszej części.

\section{Udział dzieci i młodzieży w procesach zarządzania i planowania miastem - wybrane przykłady}

Bezpośrednie uczestnictwo dzieci w zarządzaniu miastem może przybierać różne formy i najczęściej jest oparte na udziale grupy dzieci lub młodzieży w pracach władz lokalnych. W brazylijskim mieście Barra Mansa od 1998 roku ponad 6.000 dzieci jest na stałe włączonych do udziału w posiedzeniach władz miejskich, w ramach budżetu partycypacyjnego. 36 delegatów dziecięcych (18 chłopców i 18 dziewcząt w wieku 9-15) jest stałymi członkami rady miasta i zarządza rocznym budżetem o wysokości 125.000 US\$. Pieniądze przeznaczane są nie tylko na infrastrukturę związaną z wyposażeniem miejsc zabaw, ale również na sadzenie drzew, oczyszczanie ścieków, oświetlenie czy poprawę bezpieczeństwa. ${ }^{6}$

Wiek, w którym dziecko po raz pierwszy staje się uczestnikiem życia miasta jest zróżnicowany w zależności od miejsca zamieszkania i uwarunkowań kulturowych. W krajach rozwijających się następuje to szybciej niż w wysoko rozwiniętych. W 2015 roku fundacja Bernard van Leer Foundation, której misją jest wspieranie działań mających na celu zdrowy rozwój dzieci, wystąpiła z programem Urban95 Initiative, mającym na celu poprawę jakości życia najmłodszych dzieci dorastających w najbardziej niesprzyjających warunkach środowiska społeczno-ekonomicznego. Punktem wyjścia dla inicjatywy było zadanie sobie pytania, jak wygląda świat widziany oczyma dziecka o średnim wzroście $95 \mathrm{~cm}$, czyli w wieku około 3 lat, i co w związku z tym punktem widzenia można rozwiązać lub zaprojektować inaczej. Jak zorganizować przestrzeń otaczającą miejsce zamieszkania, tereny zielone czy transport publiczny. Fundacja ma na celu wspieranie inicjatyw krótkoterminowych, niskobudżetowych (do 30.000 USD) i włączających możliwie różnych aktorów działań. Przykładem działań wpisujących się w Urban95 Initiative jest projekt 'Criança Fala' (dzieci mówią), mający miejsce w Sao Paulo. Celem projektu jest budowanie pewności siebie i zdobywanie nowych umiejętności przez dzieci mieszkające w zdegradowanych obszarach Sao Paulo - przy wsparciu Any Estela Haddad, ${ }^{8}$ Działania miały zróżnicowaną formę animowania aktywności dzieci i rodzin w sąsiedzkich przestrzeniach publicznych. Skupiały się na organizacji placów do gier, boisk, i zajęć warsztatowych, zachęcając do wyjścia z domów. Osiągniętym efektem działań w Sao Paulo było zwiększenie bezpieczeństwa publicznego w strefach objętych inicjatywą. Jest to dowód na to, że obecność dzieci w przestrzeniach publicznych pozwala odzyskiwać je dla wszystkich mieszkańców.

Droga do szkoły, dla większości dzieci jest pierwszym samodzielnym zetknięciem z przestrzenią publiczną. Podstawowym kryterium, w jaki sposób dziecko pokona drogę do szkoły, jest jej bezpieczeństwo. Samodzielność wyrażająca się możliwością bezpiecznego dotarcia do szkoły jest dla większości dzieci bardzo ważnym

6 Guerra, Eliana (2002), Citizenship knows no age; children's participation in the governance and municipal budget of Barra Mansa, Brazil, Environment\&Urbanization Vol 14, No 2, pages 71-84.

7 http://www.childinthecity.eu/2016/11/16/from-the-ground-up-shifting-the-lens-of-participation-to-young-children/

8 https://bernardvanleer.org/cases/engaging-kids-making-sao-paulos-streets-safer/ 
elementem rozwoju. ${ }^{9}$ W 1971 roku w Anglii 8 na 10 dzieci chodziło do szkoły na piechotę, w 1990 ta liczba spadła do mniej niż jeden ${ }^{10}$. W krajach skandynawskich dającą się obecnie zauważyć tendencją jest zachęcanie dzieci do samodzielności w poruszaniu się po mieście. W Danii tworzy się rowerowe place zabaw, o różnej formie: od tymczasowej aranżacji przestrzeni, do trwałego zagospodarowania. Mają one być miejscami, gdzie przez zabawę najmłodsze dzieci uczą się zasad ruchu drogowego, oraz nabierają sprawności fizycznej. Wszystko to ma na celu jak najszybsze stworzenie z dziecka pełnoprawnego uczestnika ruchu drogowego.

Ciekawym przykładem włączania młodszych dzieci w procesie zarządzania miastem, jest przykład norweski projektu mającego na celu poprawę bezpieczeństwa najmłodszych w drodze do szkoły. Pilotażowy program "Traffic Agent", (Oslo), wykorzystuje aplikację na telefony komórkowe, przy użyciu której dzieci zgłaszają, szczególnie niebezpieczne ich zdaniem miejsca na drodze do szkoły. Poprzez zabawę w „tajnych agentów" do miasta wpływają cenne informacje, które byłyby trudne lub wręcz niemożliwe do pozyskania w inny sposób. Tworząca się baza danych, jest podstawą do podejmowania przez władze miasta działań na rzecz poprawy bezpieczeństwa przestrzeni, jej jakości i szeroko rozumianego dostosowania do potrzeb dzieci. ${ }^{11}$

Innym norweskim przykładem włączenia dzieci do funkcjonowania przestrzeni publicznej jest popularna idea wakacyjnego wolontariatu w skansenach. Ubrane w stroje nawiązujące do epoki dzieci spędzają w muzeach czas ucząc się gotować, haftować, opiekując się zwierzętami i uczestnicząc w codziennym życiu przedstawianego miasteczka czy wsi. Żywe skanseny są bardzo atrakcyjne również dla zwiedzających, którzy mają możliwość poznania tradycyjnych form zabudowy, zwyczajów i aktywności z udziałem prawdziwych ludzi.

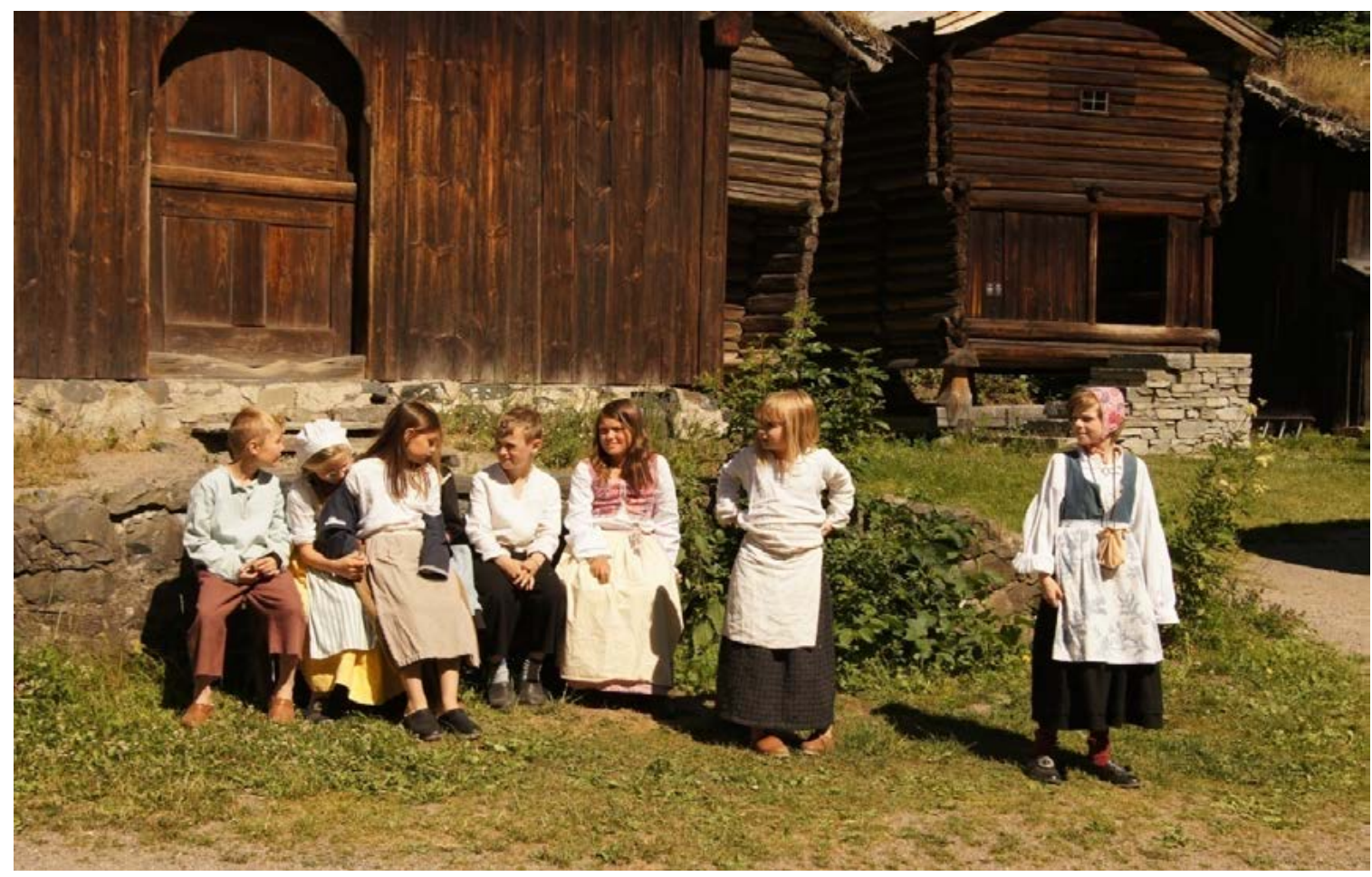

Ryc. 1. Grupa dzieci uczestniczących w zajęciach w skansenie w Oslo. Fot. N. Przesmycka 2015.

9 Zgodnie z art. 43 prawa o ruchu drogowym dziecko w wieku do 7 lat może korzystać z drogi tylko pod opieką osoby, która osiągnęła wiek co najmniej 10 lat. W obszarach zwanych strefami zamieszkania, poniżej 7 lat mogą korzystać z drogi bez opieki z uwagi na uprzywilejowanie pieszych i ograniczenie prędkości pojazdu do $20 \mathrm{~km} / \mathrm{h}$

- To oznacza, że sześcioletnie dziecko nie może samo przejść do szkoły, nawet gdy znajduje się ona 200 metrów od domu, a cała trasa biegnie wyłącznie chodnikiem - tłumaczy młodszy

10 Growing Up in a Risk Averse Society', p. 12

11 https://nextcity.org/daily/entry/oslo-app-schoolchildren-safe-walk-school 

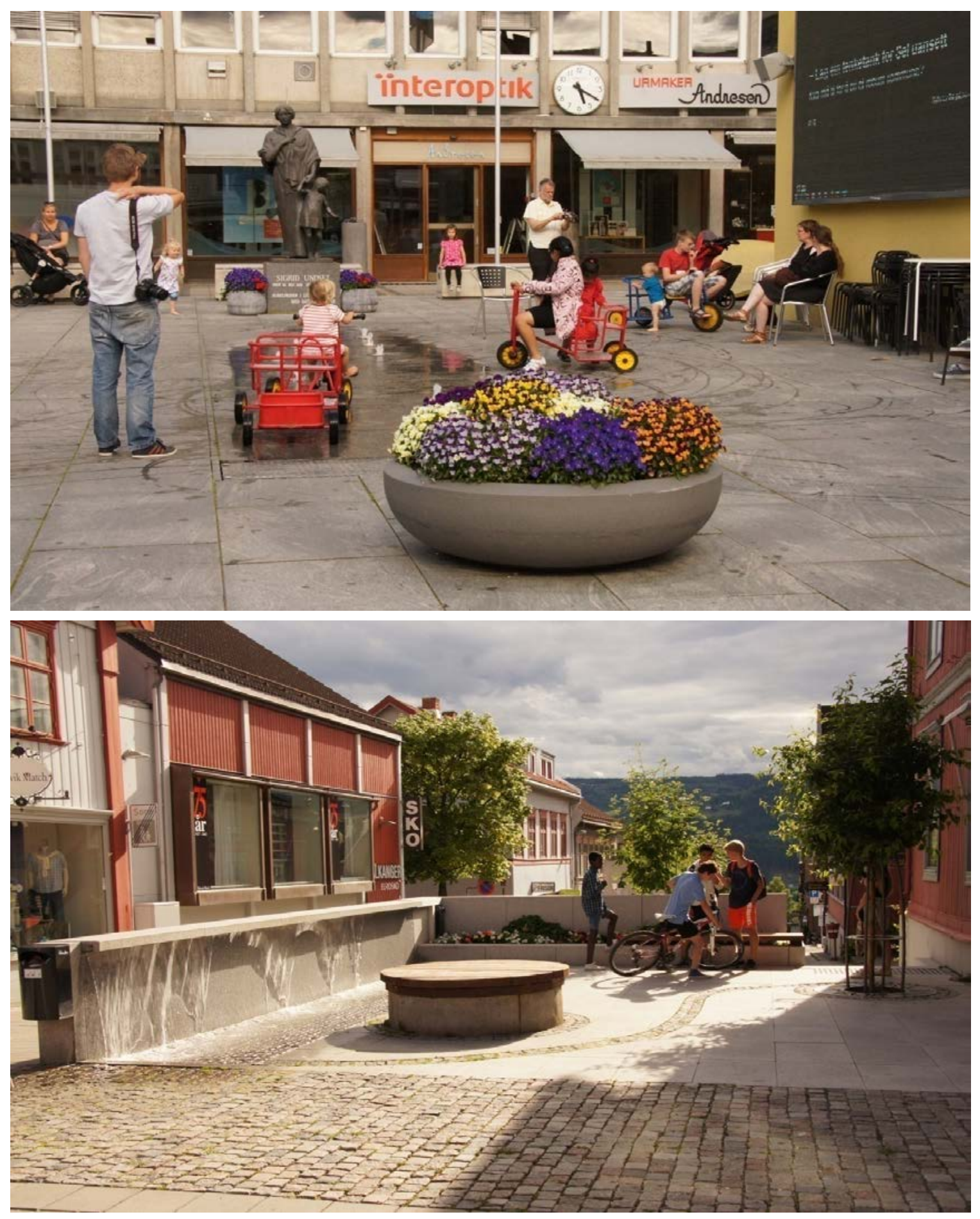

Ryc. 2. Deptak w centrum miasta jako wielofunkcyjna przestrzeń przyjazna dzieciom w różnym wieku. Woda jest elementem przyciągającym najmłodszych. Lillehammer. Fot. N. Przesmycka 2015. 


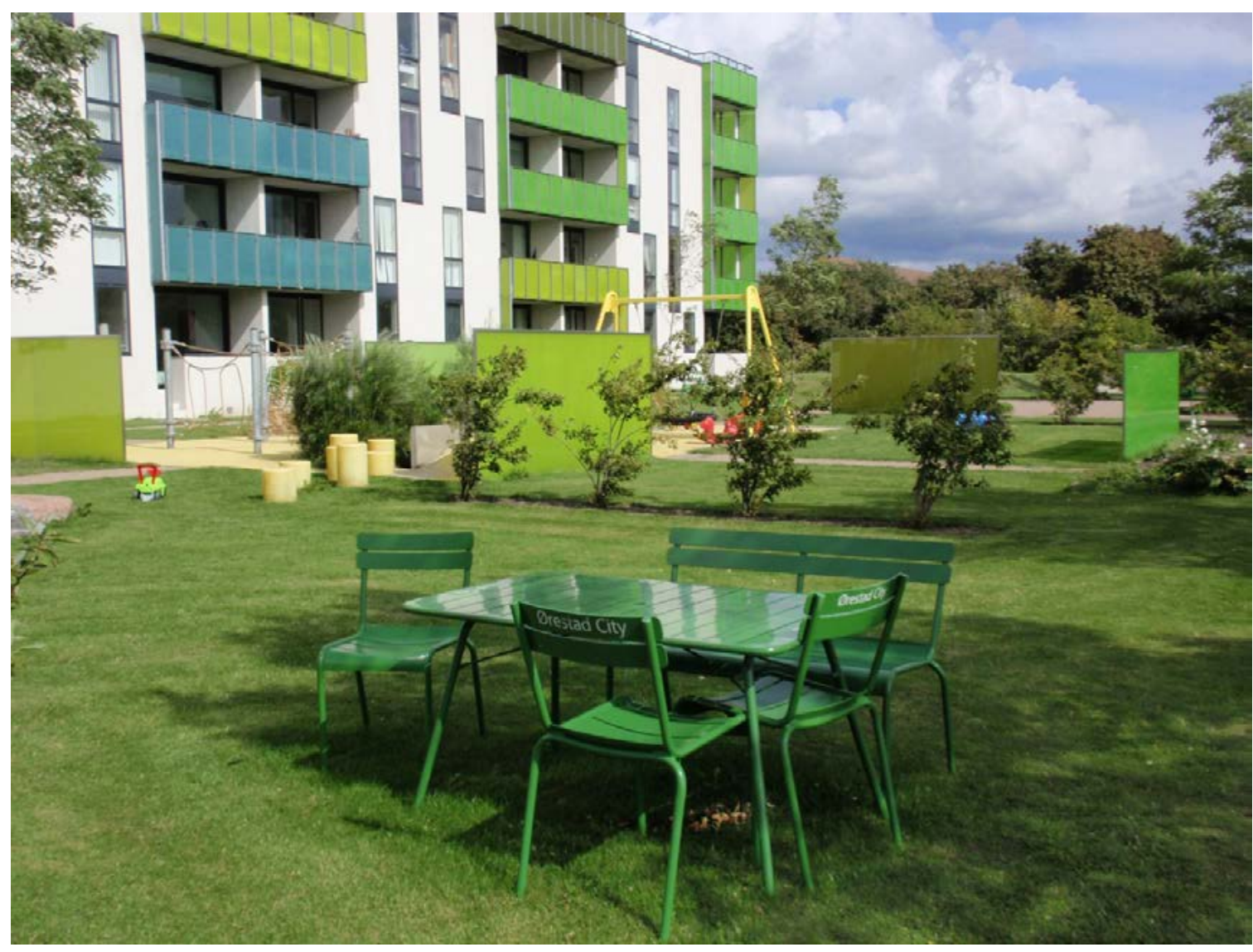

Ryc. 3. Przestrzeń sąsiedzka w dzielnicy Orestad, Kopenhaga. Miejsca zabaw dzieci łączą się z przestrzeniami aktywności dorosłych. Fot. N. Przesmycka 2015.

\section{Miasta przyjazne dzieciom i młodzieży}

Włączenie dzieci do procesu zarządzania miastami zostało wskazane w inicjatywie na rzecz miast przyjaznych dzieciom (The Child-Friendly Cities Initiative, tj. CFCI), ustanowionej przez UNICEF i UN-Habitat (United Nations Human Settlements Programme) w 1996 roku. Międzynarodowy Sekretariat CFCl identyfikując dziewięć zagadnień tematycznych, skierowanych dla lokalnych rządów, by miasta stały się „przyjazne dzieciom”, na pierwszym miejscu wskazał udział dzieci na wszystkich etapach planowanie i wdrażania działań w mieście. ${ }^{12}$

By miasto mogło uzyskać miano "Miasta Przyjaznego Dzieciom”, muszą zostać spełnione następujące kluczowe elementy: udział dzieci w procesach decyzyjnych (np. poprzez tworzenie Dziecięcych Rad Miasta), prawodawstwo przyjazne dzieciom, spójna strategia lokalna promowania praw dziecka, istnienie odpowiednich narzędzi monitorowania i oceny wpływu dzieci na lokalną politykę, posiadanie budżetu "dziecięcego", niezależne poradnictwo dla dzieci oraz lokalny odpowiednik rzecznika praw dziecka. Nieodzowne są również regularne raporty o stanie "Miasta Przyjaznego Dzieciom". Inicjatywa zazwyczaj pochodzi od lokalnych władz, współpracujących z instytucjami zajmującymi się kwestiami dzieci, ale także zdrowia, edukacji czy wydziałami planowania przestrzennego i urbanistycznego, często przy wsparciu lokalnych oddziałów UNICEF. 
„Miasta Przyjazne Dzieciom" szybko stały się ruchem rozpowszechnionym we Włoszech, Hiszpanii, krajach Ameryki Południowej ${ }^{13}$. Zupełnie inaczej wyglądają problemy dzieci z krajów wysokorozwiniętych, w których bardziej zwraca się uwagę na rekreację, prawo do zabawy. W efekcie procesy rewitalizacyjne skierowane są między innymi na rozwiązywanie potrzeb dzieci.

Przykładem interwencji architektonicznej w zaniedbanej przestrzeni publicznej, skierowanej przede wszystkim do młodzieży jest realizacja Biblioteki na wolnym powietrzu w dzielnicy Salbke, w Magdeburgu. To poprzemysłowe miasto obecnie poddawane jest procesom rewitalizacyjnym w różnej skali, które odbywają się przy udziale mieszkańców. W 1980 roku została rozebrana istniejąca w tym miejscu biblioteka publiczna. W 2005 roku idea biblioteki na świeżym powietrzu została wcielona w życie w ramach projektu "City on trial", którego celem był przede wszystkim społeczny wymiar rewitalizacji ${ }^{14}$. Zaangażowanie mieszkańców do wspólnych działań, a zarazem znalezienie pomysłu na zorganizowanie przestrzeni publicznej odbyło się poprzez nawiązanie do dawnej funkcji tego miejsca - biblioteki. Bazując na pozostałościach dawnego sklepu, na trójkątnej działce powstał w przeciągu dwóch dni - początkowo jako tymczasowa instalacja - model biblioteki w skali 1:1, zbudowany z plastikowych pojemników po piwie, z udziałem mieszkańców. Miało to stać się „rzeźbą socjalną" "social sculpture" mówi Steffan Rettich z Karo [Vitamin Green Phaidon Editors]. Półki wkrótce zapełniły się podarowanymi bibliotece książkami (20 tys. książek). Na terenie po dawnej osiedlowej bibliotece została zorganizowana przestrzeń wielofunkcyjna, skupiona wokół nieformalnego punktu wymiany książek. ${ }^{15} \mathrm{~W} 2009$ roku zrealizowano docelowy obiekt, w którym oprócz biblioteki mieści się kilka klas szkoły podstawowej i kawiarnia.

Do budowy wykorzystano elementy pochodzące z recyklinu - pozostałości po rozebranym budynku magazynowym, który znajdował się w sąsiedztwie, drewno oraz charakterystyczny zielony poliwęglan. Całość założenia tworzy ramy architektoniczne dla publicznego placu, w którym ważnym elementem jest strefa dla młodzieży: miejsce sprzyjające spotkaniom zaprojektowane wedle zasady wygodnej obserwacji, wyniesienia i oddzielenia.

Przykładem współczesnej realizacji, będącej udaną próbą humanizacji przestrzeni związanej z transportem poprzez wprowadzenia aspektu przyrodniczego jest projekt "Trzy Wyspy" w Kopenhadze. Projekt powstał przy udziale mieszkańców, w tym dzieci i młodzieży w celu urozmaicenia i ożywienia przestrzeni publicznej rozciągającej się wzdłuż kanału, pod wiaduktem kolejowym łączącym strefę centralną Kopenhagi z intensywnie rozwijającą się dzielnicą Ørestad. W trakcie konsultacji społecznych mieszkańcy wskazali swoje potrzeby: zazielenienia i ożywienia kanału i stworzenia miejsca spędzania czasu dla różnych grup wiekowych. W ramach projektu powstały trzy platformy o konstrukcji pomostów pływających zlokalizowanych w odległościach ok. $100 \mathrm{~m}$ od siebie. Najważniejsza z platform, zlokalizowana została przy publicznej szkole podstawowej i średniej oraz bibliotece. Przewodnia idea tego miejsca to edukacja ekologiczna, w formie stworzenia możliwości do obserwowania różnorodności zwierząt i roślin.

\section{Młodzież jako inicjator, wykonawca i użytkownik przestrzeni miejskich}

Przestrzenie publiczne będące ulubionymi miejscami spędzania czasu przez młodzież można sklasyfikować jako formalne i nieformalne miejsca spotkań. Obecność młodzieży w przestrzeni publicznej wiąże się z aktywnością fizyczną, najczęściej przejawiającą się uprawianiem tak zwanych sportów miejskich. Można zaobserwować zjawisko spontanicznego zawłaszczania przestrzeni przez grupy młodzieży. Co ciekawe, często młodzież anektuje sobie przestrzenie, wydawałoby się kompletnie nie atrakcyjne. Same „sporty miejskie", wywodzą się bezpośrednio z aktywności wymyślonych przez młodzież szukającą wrażeń w kontakcie z przestrzenią miasta (np. parkur, lacrosse, ultimate frisbee, bike polo, BMX, longboard czy wakeboard). Obecnie coraz istotniejszymi elementami krajobrazu miejskiego stają się skateparki, mniejsze skatespoty, siłownie czy strefy do street workoutu. Przestrzenie te służą nie tylko do uprawiania sportów ekstremalnych, ale przede wszystkim do spotkań

13 Eliana Riggio, Environment\&Urbanization, Vol 14 No 2 October 200245CHILD FRIENDLY CITIES. Child friendly cities: good governance in the best interests of the child.

14 David Bravo, http://www.publicspace.org/en/works/f084-open-air-library

15 Proj. Karo Architekten. W 2011 roku projekt został nagrodzony w Brit Insurance Design of the Year Awards 2011. Sędziom spodobał się nie tylko oryginalny wygląd obiektu, ale przede wszystkim otwarty sposób funkcjonowania biblioteki. 
towarzyskich. Inicjatorami ich powstawania jest najczęściej młodzież lub młodzi dorośli, którzy sympatyzują tym dyscyplinom.

Wśród wielu inicjatyw lokalnych, skateparki początkowo często spotykają się z niechęcią, kojarząc się z hałasem, graffiti, narkotykami itd. Jednak w rzeczywistości skaterzy czują się silnie związani z użytkowaną przez siebie przestrzenią i dbają o nią. W obrębie grupy użytkowników tych przestrzeni zawiązują się więzi społeczne: starsi opiekują się początkującymi dając im wskazówki [Morello, 2014]. Sukces skateparku zależy przede wszystkim od zaangażowania przedstawicieli lokalnej społeczności w jego powstawanie na każdym etapie. Dobrze zaprojektowane skateparki mogą stać się atrakcją o zasięgu ponad lokalnym, przyciągając skaterów z innych miast a nawet krajów. W przypadku skateparków kluczowa jest jakość przestrzeni, jaką zaoferuje się użytkownikom. Nie powinno oszczędzać się na solidności i jakości wykonania skateparku, a wprowadzenie tej funkcji do planowania miastem może przynieść długotrwałe efekty również w wymiarze finansowym, co pokazuje przykład FDR Skatepark w Filadelfii [Nims 2008].

Projekt skateparku w hiszpańskim mieście Arbúcies (Girona) jest przykładem pełnej partycypacji młodzieży na każdym etapie jego powstawania Sk8+U. Inicjatorem była grupa dzieci i młodzieży w wieku od 11 do 17 lat, która udała się w 2011 roku do władz miasta z prośbą o organizację skateparku. Po serii spotkań młodzieży z władzami miasta wskazano nowo powstające tereny sportowe w rejonie Can Pons, jako najbardziej odpowiednie miejsce. Młodzież była nie tylko liderem i inicjatorem projektu, ale również uczestnikiem procesu projektowania i powstawania, a w konsekwencji zarządcą przestrzeni. Pomimo skromnego budżetu, udało się wykonać solidną betonową misę. W trakcie trwania projektu cyklicznie organizowano warsztaty, na których młodzież nauczyła się jak wykonać mieszkankę betonową i szalunki. Dzięki użyciu materiałów pochodzących z recyklingu (między innymi starych barier dla bydła, i pozostałości po konstrukcjach drogowych) ${ }^{16}$, powstał niskobudżetowy skatepark. Młodzi ludzie zainteresowali swoją ideą znanego projektanta skateparków Sergi Arenasa. Kupiony za cenę złomu okrętowy kontener służył podczas budowy jako magazyn, zaplecze socjalne, a z czasem stał się stałym miejscem spotkań użytkowników skateparku.

Miejsca zaprojektowane dla młodzieży muszą być przez nią całkowicie zaakceptowane. Ta grupa społeczna nie zadowoli się rozwiązaniami nie do końca im odpowiadającymi. Dobra przestrzeń staje się miejscem, z którym grupa społeczna się identyfikuje, szanuje je, dba o nie, a w razie potrzeby przebudowuje i zmienia. Skateparki i inne miejsca dla młodzieży często są chętnie odwiedzane przez starszych mieszkańców, którzy z przyjemnością podziwiają karkołomne triki i wyczyny sportowe. Przestrzenie dla młodzieży, jak żadne inne potrzebują być projektowane przy jej czynnym udziale.

\section{Bibliografia}

[1] Bartlett S., Building better cities with children and youth. Environment and Urbanization, 2002, 14, 3-10., Driskell D., Creating better cities with children and youth: a manual for participation. UNESCO.

[2] Bartlett, Sheridan, Roger Hart, David Satterthwaite, Ximena de la Barra and Alfredo Missair (1999), Cities for Children: Children's Rights, Poverty and Urban Management, Earthscan, London, 305 pages.

[3] Czałczyńska-Podolska M., 2012. Czynniki efektywnego planowania i kształtowania terenów rekreacji w mieście. Teka Kom. Arch. Urb. Stud. Krajobr. - OL PAN, VIII/1, str. 35-45.

[4] Hart R. (1992), Children participation. From tokenism to citizenship, UNICEF Innocenti Centre, Florence.

[5] http://www.mlodziezmawplyw.org.pl/files/publikacje/Partycypacja_dzieci.pdf, Maja Brzozowska-Brywczyńska Partycypacja publiczna dzieci, ANALIZY I OPINIE Numer specjalny 4 marzec 2013 „Decydujmy razem”

[6] http://www.mlodziezmawplyw.org.pl/files/publikacje/Partycypacja_dzieci.pdf, Maja Brzozowska-Brywczyńska Partycypacja publiczna dzieci, ANALIZY I OPINIE Numer specjalny 4 marzec 2013 „Decydujmy razem”

[7] http://www.playengland.org.uk/media/70684/design-for-play.pdf

[8] Jansson M., 2015, Children's perspectives on playground use as basis for children's participation in local play management, Local Environment, Vol. 20, No. 2, 165-179.

[9] Jarosz E., Partycypacja dzieci a rozwój zaangażowania obywatelskiego, Pedagogika Społeczna, r. 15, 2016, nr 2 (60), s. 67-87 
[10] Johanna Agerman Ross, open-Air library, Vitamin Green, 2012, Phaidon Press, p. 222-223

[11] Konwencja o prawach dziecka, przyjęta przez Zgromadzenie Ogólne Narodów Zjednoczonych dnia 20 listopada 1989 r. Dz.U. 1991 nr 120 poz. 526

[12] Kozlovsky R., 2013,The Architectures of Childhood: Children, Modern Architecture and Reconstruction in Postwar England.

[13] Lansdowne G. (2010), Addressing the balance of power, [w:] Valuing children's potentials, M. Shuurman (red), Brussels.

[14] Libura H., 1990, Percepcja przestrzeni miejskiej, Uniwersytet Warszawski, Instytut Gospodarki Przestrzennej, Rozwój regionalny - Rozwój lokalny - Samorząd terytorialny, nr 31, Warszawa 1990,

[15] Lynch K. Growing up in cities: studies of the special environment of adolescence in Cracow, Melbourne, Mexico City, Salta, Toluca and Warsaw, Cambridge, MA; MIT Press, 1977, 177 pp. W czterach krajach przebadano po 20 nastolatków, co uznawane było za niewystarczające i zbyt mało reprezentatywne jako wyniki badań, Są to bardziej impresje niż fakty, jednak cenne jest samo zwrócenie uwagi na potrzeby młodych ludzi.

[16] Lynch K. Growing up in cities: studies of the special environment of adolescence in Cracow, Melbourne, Mexico City, Salta, Toluca and Warsaw, Cambridge, MA; MIT Press, 1977, 177 pp

[17] Morello P., 2014, Skateparks-a Key to Community Engagement, Parks \& Recreation, May 2014, s. 67-69.

[18] Newman M., Thomas P. Student participation in school design: one school's approach to student engagement in the BSF process. CoDesign, 2008, 4, 237-251.

[19] Nims J., 2008, Built skater though, Praks \& Recreation, 08 2008, s. 39-42

[20] Percy-Smith B., 1998, Children's participation in local decision-making the challenge for local governance, [w:] Stepping forward: children and young people's participation in the development process, V. Johnson, E. Ivan-Smith, G. Gordan, P. Pridmore, P. Scott (red.), It Publication, London

[21] Scott S., 2010, Architecture for Children, By:, Sarah; Australian Council for Educational Research. Camberwell, Vic : ACER. 2010. eBook., Baza danych: eBook Collection (EBSCOhost)

[22] Taylor M., Percy-Smith B., 2008, Children's participation: learning from and for community development, "International Journal of Children's Rights", Vol. 16, p. 379-394 